\title{
Pesticides Usage in the Soil Quality Degradation Potential in Wanasari Subdistrict, Brebes, Indonesia
}

\author{
Tri Joko, ${ }^{1,2}$ Sutrisno Anggoro, ${ }^{1,3}$ Henna Rya Sunoko,, ${ }^{1,4}$ and Savitri Rachmawati ${ }^{2}$ \\ ${ }^{1}$ Doctoral Program of Environmental Science, School of Postgraduate Studies, Diponegoro University, Semarang City, Indonesia \\ ${ }^{2}$ Public Health Faculty, Diponegoro University, Semarang City, Indonesia \\ ${ }^{3}$ Faculty of Fisheries and Marine Science, Diponegoro University, Semarang City, Indonesia \\ ${ }^{4}$ Faculty of Medicine, Diponegoro University, Semarang City, Indonesia
}

Correspondence should be addressed to Tri Joko; trijokoundip@gmail.com

Received 17 February 2017; Revised 15 May 2017; Accepted 30 May 2017; Published 3 July 2017

Academic Editor: Marco Trevisan

Copyright (C) 2017 Tri Joko et al. This is an open access article distributed under the Creative Commons Attribution License, which permits unrestricted use, distribution, and reproduction in any medium, provided the original work is properly cited.

Uncontrolled application of pesticides can contaminate soil and may kill other nontarget organisms. This study aims to determine the usage pattern of pesticides by farmers in Wanasari Subdistrict and study the soil quality degradation potential. This study was a quantitative and qualitative research. Sources of data were collected from observation, questionnaire, and in-depth interview methods. The respondents were shallot farmers who planted shallot during 2013-2016 $(n=60)$. In-depth interview was done with three respondents from the local agricultural extension center (BPP). This study found that there were some different types of insecticides and fungicides that were used in every planting season. The farmers applied pesticides in large amount once every three or four days. They mixed minimally three insecticides and fungicides types about 30-40 ml for each type. Organophosphate residues that were found in soil samples were methidathion residue about $0.014 \mathrm{mg} / \mathrm{kg}$, malathion residue ranging around $0.1370-0.3630 \mathrm{mg} / \mathrm{kg}$, and chlorpyrifos residue in the range of $0.0110-0.0630 \mathrm{mg} / \mathrm{kg}$. The excessive application of pesticides showed the land degradation potential. Soil quality laboratory testing is recommended to ensure the agricultural land condition. Routine assessment of soil quality and pesticide usage control is recommended to keep sustainable ecosystem.

\section{Introduction}

Uncontrolled application of pesticides can contaminate soil and may kill other nontarget organisms. Pesticides can damage soil biomass and microorganism such as bacteria, fungi, and earthworms. Microbial biomass is a labile component of soil organic matter and has an important role in soil nutrient element cycle [1]. S. A. Reinecke and A. J. Reinecke (2007) had studied earthworm biomass and cholinesterase activity affected by pesticides [2]. The authors concluded that earthworms were affected detrimentally by the pesticides due to chronic (chlorpyrifos) and intermittent exposure (azinphos methyl). Other research also showed that malathion exposure gave the significant reduction in body weight and decreased sperm viability of Eisenia fetida adults species. The organism also had an adverse impact on growth and reproduction by the chlorpyrifos exposure, and the cypermethrin exposure also gave the significant reduction in cocoon production [3-6]. Pesticides which are applied to the soil could have an impact on nontarget organisms and damage the local metabolism that is required by soil fertility and pesticide degradation itself [7-11]. The large pesticides application and its impact can be identified in Indonesian shallot farming.

Some of the data showed that shallot productivity by Indonesian farmers became nonoptimal because of several factors. The factors that affected the productivity of shallot farming are improper cultivation technique, uncontrollable environmental factor, pest attack, and plant disease [12, 13]. In order to control the pest and plant disease, farmers apply pesticides excessively. Wanasari Subdistrict is one of the agricultural centers in Brebes which produces shallot (Allium cepa $\mathrm{L}$ ). Wanasari located at least $2 \mathrm{~km}$ from the downtown. The usage of pesticides increases every year, including in this region. The emergence of new pesticides enables farmers 
to try any type of them. The habit of trying every type of new pesticides has happened in Wanasari Subdistrict. On the other hand, socialization and advocacy regarding the procedure for safety usage of pesticides have been carried out by the local agricultural institute, in Indonesia known as Balai Penyuluh Pertanian (BPP) or called agricultural extension center. However, the socialization is not optimal and the farmers still apply pesticides to the land with an excessive amount. The enhancement of pesticides that were used by farmers happens not only in a rural area of Indonesia but also in urban area.

The enhancement of agricultural production associated with more intensive use of pesticides including insecticides. It is assumed that in 2050 the use of pesticides will be 2.7 times greater than in 2000. This will cause humans and the environment to be in a dangerous condition [14, 15]. There were many references about the impact of pesticides on soil and water environment. The excessive application of pesticides also causes pest resistance, and this condition also occurred in Wanasari Subdistrict. Resistance is a natural phenomenon. Even as the introduction of new classes of insecticides such as cyclodienes, carbamates, formamidines, organophosphates, and pyrethroids, new resistant cases that appeared were reported in the period of 2-20 years. Pest resistance resulted in the fact that farmers must increase the dose of pesticides that are used; even the addition could be 2-3 times the amount added before.

This study aims to determine the usage pattern of pesticides by farmers in Wanasari Subdistrict. In this study, potential degradation for agricultural soil quality was also reported. Data and information obtained from this research then can be used as the basis for further research to determine the relationship between the pesticide applications to soil parameter degradation quantitatively.

\section{Materials and Methods}

2.1. Time and Study Area. This research was conducted from August 2016 until January 2017 located at Wanasari Subdistrict, Brebes District, Central Java Province, Indonesia. The location of the study was selected based on the shallot productivity criteria level and pesticide usage behavior.

2.2. Interview and Questionnaire. This study was a quantitative and qualitative research. Sources of data were collected from observation, questionnaire, and in-depth interview. The respondents for quantitative study were shallot farmers who planted shallot during the last three years $(n=60)$. The interviews were conducted with three official officers from the local agricultural extension center, known as Balai Penyuluh Pertanian (BPP). Data were presented descriptively by outlining the existing findings of observations and respondents interview. Interviews were conducted to determine the pattern of shallot planting in the study area, the pattern of pesticide usage, which includes the types of pesticides, how to mix the pesticides for spraying, and time of pesticides use based on the planting period. Instruments used in this study are questionnaires, notebook, and recorder. The questionnaires were inputted to Microsoft Office Excel for descriptive analysis. The data analysis was presented in tables and graphs. In-depth interview was carried out to determine the role of BPP in the use of pesticides and also to validate the findings of the questionnaires.

2.3. Soil Sampling and Organophosphate Residue Testing. Soil sampling methods were done randomly. Soil samples were taken throughout the sampling locations at the same time. The sampling was conducted during the dry season. Soil samples were taken at $25-50 \mathrm{~cm}$ depth, and the top soil was not included in the sample. Soil samples were collected using a tube sampler and then stored in a clean plastic bag. Samples are labeled according to the date of sampling, sample locations, and types to be tested. Then the samples were sent to the lab to be tested. The measurement method of pesticide residues is using Gas Chromatography-Mass Spectrometry (GC-MS) in the Agrochemicals Residue Laboratory, Indonesian Ministry of Agriculture. The result is expressed in units of $\mathrm{mg} / \mathrm{kg}$.

2.3.1. Tools and Materials. The tools used in this study were mechanical shaker (shaker), Florisil columns, glassware, rotary evaporator, homogenizer, vacuum pump, Buchner filter, water bath, analytical scales, and a Gas Chromatography set (GC-2014 Shimadzu) equipped with ECD and Rtx-1 columns (column length $30 \mathrm{~m}$, inner diameter $0.25 \mathrm{~mm}$ ). Materials used in the study were acetone (E. Merck), n-hexane (E. Merck), anhydrous $\mathrm{Na}_{2} \mathrm{SO}_{4}$ (E. Merck), Florisil, activated carbon, Celite 545-magnesium, filter paper, aquadest, standard solution of organophosphate pesticides, and soil samples.

2.3.2. Soil Sampling. The ground surface to be sampled is flattened and cleaned; then the soil was dug with a soil corer perpendicular to the layer. The soil was taken to $25-30 \mathrm{~cm}$ depth. Next, the soil around the tube was dug up with a shovel. About $1-2 \mathrm{~cm}$ of the topsoil was removed. Then \pm 250 grams of soil was leveled and sampled. The soil samples were then placed on the sample plastic and labeled with sample codes, sampling dates, sample locations, and test types. Samples that had been prepared then were immediately sent to the laboratory. Sample delivery should be safe to avoid damage or torn plastic. The delivery time was about 2-3 days.

2.3.3. Preparation of Soil Samples. Dried soil sample (by aerated method) weighed about 25 grams and then was put into a round bottom flask and $100 \mathrm{ml}$ acetone solvent was added and then closed. The round bottom flask containing the sample was shaken with a shaker for 20 minutes at a sufficient rate. After $20 \mathrm{~min}$, the extraction was repeated by rewinding with the same time and velocity; then the separating funnels were placed on the iron stand with clamp and remained until separation occurred between the solvent and the sample; then separation between filtrate and residue occurred. The filtrate was evaporated with an evaporator, extracted with $25 \mathrm{ml}$ of $\mathrm{n}$-hexane 2 times, and then cleaned up by passing the sample on the chromatographic column filled with Florisil and anhydrous sodium sulfate. Eluate was evaporated until $\pm 1 \mathrm{ml}$ then the flask was rinsed with acetone gradually and 
the result was collected in test tube up to $10 \mathrm{ml}$ volume and the sample solution was ready to be injected into the Gas Chromatography.

2.3.4. Organophosphate Residue Testing. Analysis of pesticide residues of organophosphate groups in soil samples was carried out by the method used by the Agrochemical Residue Laboratory of Balingtan (Balai Penelitian Lingkungan Pertanian). The solutions obtained from the extraction of soil samples determine the residual content of the organophosphate by the results of Gas Chromatography (GC-2014 Shimadzu).

\section{Results and Discussion}

3.1. Planting Time Pattern in the Study Area. Wanasari Subdistrict is one of the shallot agricultural centers in Brebes. Wanasari Subdistrict drained Pemali River which is used in the irrigation. Pemali River flows throughout the year, but the reduction of water discharge may occur in dry season. This hydrology conditions influence the shallot planting time and productivity based on its area. Shallot planting times vary depending on the regions. Wanasari Subdistrict stretches from north to south covering an area of 7,226 ha consisting of 2,123 ha of agricultural land using technical irrigation area, 632 ha using semitechnical irrigation, and rainfed area about 1,346 ha. In general, Wanasari Subdistrict has four shallots planting periods per quarter throughout the year, the first planting is in January-March, the second planting is in April to June, the third growing season is in July-September, and the fourth growing season is in October-December. In addition, farmers also plant paddy, red peppers, green beans, bitter melon, peanuts, eggplants, tomatoes, cucumbers, and beans. Shallot was grown throughout the year, while rice and chili are planted during two periods. Paddy field for planting shallot has the widest area compared to other crops. Data from the Agricultural Extension Center of Wanasari Subdistrict showed in 2014 shallot harvest in Wanasari reached 6120 hectares; then the paddy areas are about 3800 hectares.

The irrigated areas by Pemali River were Dukuhwringin, Dumeling, Glonggong, Jagalempeni, Kertabesuki, Lengkong, Pesantunan, Siasem, Sidamulya, and Wanasari village. The small part areas of the irrigation river are Pebatan and Sawojajar village. Areas that do not irrigate by the Pemali River are Keboledan, Klampok, Kupu, Sigentong, Sisalam, Siwungkuk, Tanjungsari, and Tegalgandu, but there are discharge channels as a source of irrigation. Pemali River flow across most of villages in Wanasari Subdistrict has benefit for agricultural area. Farmers can plant shallot along the year because of the abundance of water. The rainy season which occurs in the range from October to March also brings benefits for the area as a part of irrigation system in the location. With the availability of sufficient water, it can guarantee that shallot can be continued to be planted in this area.

3.2. Pesticides Usage Pattern among Farmers in the Study Area. Observations and interviews with farmers showed the classified patterns of pesticides excessive application. When spraying, farmers mixed the pesticide at least 2-3 types and there could even be 5-7 types. The doses used were

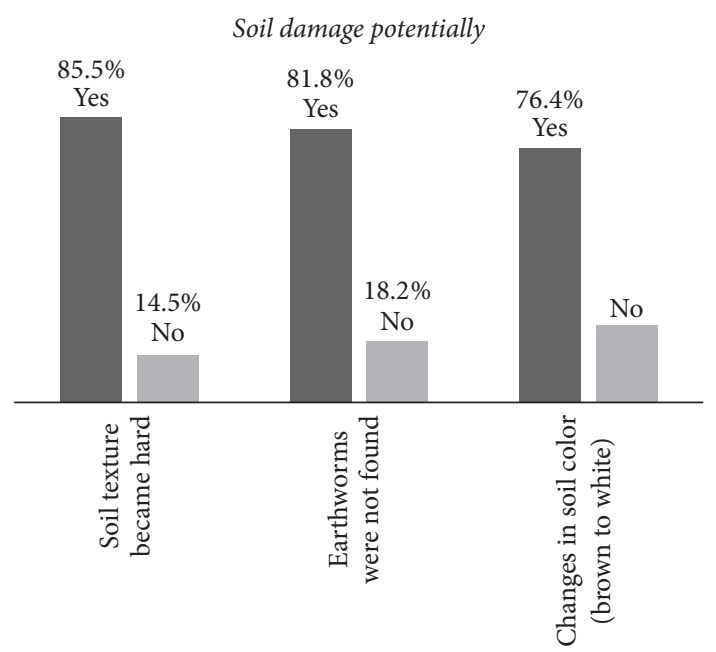

FIGURE 1: Degradation potential of soil quality.

$30-40 \mathrm{ml}$ per type. Certainly the application of pesticides was tailored to the pest attack and shallot plant disease. The excessive pesticide applications become uncontrolled in a pest explosion event, when the pests attack less than usual the usage of insecticides reduced. When spraying, farmers used the spray tank that has 15 or 17 liters' capacity. For the fields of $1000 \mathrm{~m}^{2}$, it takes at least two tanks for spraying once. If farmers used pesticides of at least 3 mixtures of $30 \mathrm{ml}$ per species, then a tank containing $90 \mathrm{ml}$ of pesticides was sprayed. For the $1000 \mathrm{~m}^{2}$ land at least $180 \mathrm{ml}$ pesticides were sprayed. When this amount is calculated up to the time of the year it could be demonstrated that there were many pesticides absorbed by the ground.

The pattern of insecticides usage in shallot agriculture varies. The amount of insecticides used has different mixed pattern in each cropping period, or with the fungicides usage. However, farmers often mixed between insecticides and fungicides. In the first growing season in January to March farmers generally use four types of mixtures (variation between insecticides and fungicides). The types often used in this season were Arjuna, Tumagon 100 EC, Daitin, and Vondozeb. The second planting season is in April, May, and June; an increasing number of the mixtures are used, which can be up to five mixtures. In the third growing season from July to September the farmers do not use fungicides. When the second and third growing season are in dry season and pests attack increased, the use of insecticides is done in large numbers. Shallot had little of plant disease and it was not found during the dry season. This has led to the reduction of fungicide usage. In the fourth growing season in October-December, the opposite things occurred. These months already entered the rainy season so that pests diminish; shallot plant disease increases. These conditions led to the fact that the usage of insecticides was not much required, and the usage of fungicides increased (Table 1).

3.3. Types of Pesticides Mostly Used by Farmers. Insecticides and fungicides are used by many farmers in the shallot crop. Basically insecticides are used to control pests of plants, and 
TABLE 1: Agriculture planting time in Wanasari Subdistrict.

\begin{tabular}{|c|c|c|c|c|}
\hline \multicolumn{5}{|c|}{ Planting time } \\
\hline I & & II & III & IV \\
\hline $\begin{array}{l}\text { Insecticides used } \\
\text { Arjuna } \\
\text { Tumagon } \\
\text { Fungicides used } \\
\text { Daitin } \\
\text { Vondozeb }\end{array}$ & & $\begin{array}{c}\text { Insecticides used } \\
\text { Dursban } \\
\text { Arjuna } \\
\text { Marshal } \\
\text { Fungicides used } \\
\text { Folicur } \\
\text { Vondozeb } \\
\end{array}$ & $\begin{array}{l}\text { Insecticides used } \\
\text { Arjuna } \\
\text { Trigard } \\
\text { Fungicides used } \\
\text { Not required }\end{array}$ & $\begin{array}{l}\text { Insecticides used } \\
\text { Dursban } \\
\text { Fungicides used } \\
\text { Amistar top } \\
\text { Dithane }\end{array}$ \\
\hline Jan $\quad$ Feb & Mar & Apr $\quad$ May & August & Nov \\
\hline $\begin{array}{l}\text { Pest } \\
\text { Beet armyworm } \\
\text { Spodoptera exigua L } \\
\text { Liriomyza } \\
\text { huidobrensis } \\
\text { (serpentine leafminer) } \\
\text { Disease } \\
\text { Purple blotch } \\
\text { (Alternaria porri) } \\
\text { Fusarium vascular wilt } \\
\text { (Fusarium oxysporum) } \\
\text { Downy mildew } \\
\text { Anthracnose } \\
\text { Downy mildew } \\
\text { (Peronospora destructor) }\end{array}$ & & $\begin{array}{c}\text { Pest } \\
\text { Beet armyworm } \\
\text { Spodoptera exigua L } \\
\text { Liriomyza } \\
\text { huidobrensis } \\
\text { Grasshopper pest } \\
\text { Purple blotch } \\
\text { (Alternaria porri) } \\
\text { Fusarium vascular wilt } \\
\text { (Fusarium oxysporum) } \\
\text { Downy mildew } \\
\text { (Peronospora destructor) }\end{array}$ & $\begin{array}{c}\text { Pest } \\
\text { Beet armyworm } \\
\text { Spodoptera exigua L } \\
\text { Liriomyza } \\
\text { huidobrensis } \\
\text { Taro caterpillar Spodoptera litura } \\
\text { Thrips parvispinusDisease } \\
\text { Hardly found }\end{array}$ & $\begin{array}{c}\text { Pest } \\
\text { Hardly found } \\
\text { Disease } \\
\text { Purple blotch } \\
\text { (Alternaria porri) } \\
\text { Fusarium vascular wilt } \\
\text { (Fusarium oxysporum) } \\
\text { Downy mildew } \\
\text { Anthracnose } \\
\text { Downy mildew } \\
\text { (Peronospora destructor) }\end{array}$ \\
\hline
\end{tabular}

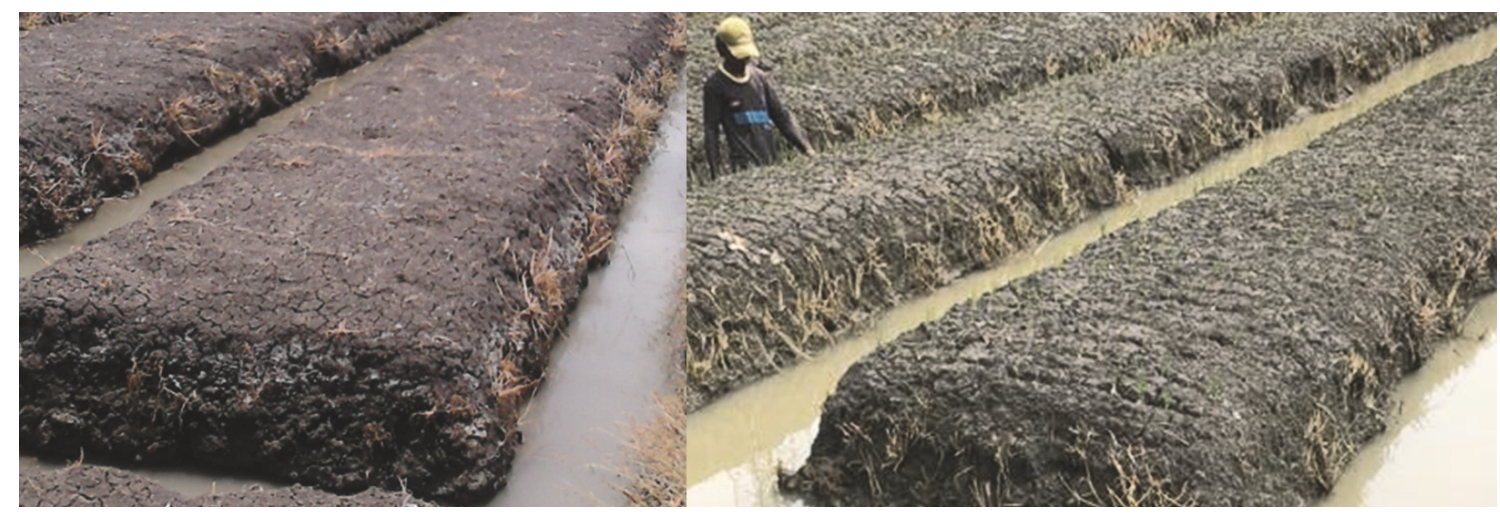

FIGURE 2: Hard soil texture and brown-white color soil, taken from agriculture area in Wanasari. Source: researcher documentation.

fungicides are used to save crops from disease. The study showed that Arjuna was the type of favorite pesticide most used by farmers (96\%). Arjuna is a kind of insecticide that contains chlorfenapyr active ingredient from pyrrole group. The insecticide was classified as moderately hazardous by WHO. Furthermore, there was Tumagon insecticide used by $90 \%$ of respondents. Trigard insecticide that contains cyromazine active ingredient is widely used by $83 \%$ of farmers, and $81 \%$ of farmers use Antracol insecticides. Other types of insecticides that are widely used are Xtreme (80\%), Dursban (75\%), Sumo (52\%), and Marshal (48\%). Active ingredients contained in widely used insecticide are pyrrole, carbamates, tiadiazin, and organophosphates (Table 2, Figure 1).

The chlorfenapyr active ingredient is used to decontaminate armyworm (Spodoptera litura) and pest thrips (Thrips parvispinus). Chlorpyrifos and beta-cyfluthrin are also used to eradicate armyworm. Propineb active ingredient is used to treat purple spots disease on shallot. The usage of insecticides increased in three to six months (March-June) and decreased in July to September; even the usage of these insecticides was getting slight in October to December. The results of in-depth interviews with farmers in Wanasari Subdistrict showed that there were many insecticides' usage in the dry season months because pests attacking occurs in dry season. Meanwhile, when the usage of insecticide was declining, the usage of fungicide increased. Fungicides were widely used, especially in the rainy season. Increased rainfall causes crop diseases emergence, especially the shallot crop.

Table 2 showed that the average dose of insecticide with chlorfenapyr active ingredient has the highest amount about 
TABLE 2: List of most insecticides and fungicides previously approved for use on shallot cultivation in Wanasari Subdistrict.

\begin{tabular}{|c|c|c|c|c|c|c|c|}
\hline Number & $\begin{array}{l}\text { Types of } \\
\text { pesticides }\end{array}$ & $\begin{array}{c}\text { Formulation } \\
\text { name }\end{array}$ & $\begin{array}{c}\text { Active } \\
\text { ingredients }\end{array}$ & Group & $\begin{array}{l}\text { Class by } \\
\text { WHO }\end{array}$ & $\begin{array}{c}\text { Pesticides } \\
\text { usage } \\
(n=60)(\%)\end{array}$ & Mean $\pm \mathrm{SD}^{*}$ \\
\hline (1) & Insecticides & Arjuna & Chlorfenapyr & Pirol & II & 96 & $34.47 \pm 0.93$ \\
\hline (2) & Insecticides & Tumagon & Buprofezin & Tiadiazin & III & 85 & $33.51 \pm 1.70$ \\
\hline (3) & Insecticides & Dursban & Chlorpyrifos & Organophosphate & II & 60 & $34.64 \pm 2.91$ \\
\hline (4) & Insecticides & Marshal & Carbosulfan & Carbamate & II & 52 & $34.42 \pm 2.27$ \\
\hline (5) & Insecticides & Sumo & $\begin{array}{c}\text { beta- } \\
\text { Cyfluthrin }\end{array}$ & Pyrethroid & $\mathrm{Ib}$ & 45 & $34.81 \pm 3.06$ \\
\hline (6) & Insecticides & Trigard & Cyromazine & Urea & III & 23 & $33.57 \pm 4.00$ \\
\hline (7) & Fungicides & Antracol & Propineb & Carbamate, organozinc & $\mathrm{U}$ & 88 & $34.85 \pm 1.51$ \\
\hline (8) & Fungicides & Delsene & Mancozeb & Dithiocarbamate, organomanganese & $\mathrm{U}$ & 82 & $34.06 \pm 1.75$ \\
\hline (9) & Fungicides & Vondozeb & Mancozeb & Dithiocarbamate, organomanganese & $\mathrm{U}$ & 63 & $34.05 \pm 2.78$ \\
\hline (10) & Fungicides & Folicur & Tebuconazole & Triazole & II & 53 & $34.19 \pm 2.24$ \\
\hline (11) & Fungicides & Amistar top & Azoxystrobin & Pyrimidine & $\mathrm{U}$ & 47 & $34.29 \pm 3.06$ \\
\hline (12) & Fungicides & Dithane & Mancozeb & Dithiocarbamate, organomanganese & $\mathrm{U}$ & 27 & $33.69 \pm 3.91$ \\
\hline
\end{tabular}

* Average dose used per 15-liter tank (ml); classes information: Ib is highly hazardous, II is moderately hazardous, III is slightly hazardous, and U is unlikely to present acute hazard in normal use. $\mathrm{U}=$ unlikely to present acute hazard in normal use.

$34.47 \mathrm{ml}$ compared to other insecticides and it was used by $96 \%$ of respondents. Insecticides with buprofezin active ingredient are used by $85 \%$ of respondents, with an average of $33.51 \mathrm{ml}$ dose used. Chlorpyrifos active ingredient is used by $60 \%$ of respondents with average dose $34.64 \mathrm{ml}$ used. Carbosulfan insecticide with beta-cyfluthrin and cyromazine active ingredients is used by $52 \%$ of respondents $(34.42 \mathrm{ml})$, $45 \%$ of respondents $(34.81 \mathrm{ml})$, and $23 \%$ of respondents $(33.57 \mathrm{ml})$, respectively.

Table 2 showed that $88 \%$ of respondents use Antracol fungicide with propineb active ingredient. The average dose used in this type of fungicide was $34.85 \mathrm{ml}$. Fungicides with mancozeb active ingredient have different formulation names including Delsene, Vondozeb, and Dithane. A total of $82 \%$ respondents used Delsene fungicide with an average dose of $34.06 \mathrm{ml}, 63 \%$ of respondents used Vondozeb fungicide with an average dose of 34.05 , and $27 \%$ of respondents used Dithane with an average dose of $33.69 \mathrm{ml}$. In addition, Folicur fungicide with tebuconazole active ingredient was used by $53 \%$ of respondents with an average dose of $34.19 \mathrm{ml}$, and Amistar top fungicide with azoxystrobin active ingredient was used by $47 \%$ of respondents with an average dose of $34.29 \mathrm{ml}$.

3.4. Pesticides Residue in Soil. We took soil samples and tested the pesticide residues to determine whether there are pesticides that are still accumulating in the soil or not after spraying activity. Soil samples were taken at several locations of shallot agricultural area in Wanasari Subdistrict. Pesticide residue of the samples was tested by agricultural research centers of the Indonesian Ministry of Agriculture (Table 3).

In this study, chlorpyrifos residue active ingredient was found in samples from all locations about 0.01 to $0.06 \mathrm{mg} / \mathrm{kg}$.
Insecticide which contains chlorpyrifos active ingredient is still used widely by shallot farmers. One type of pesticides which contains chlorpyrifos active ingredient is called Dursban. Adsorption of pesticides to the soil increases the persistence of chlorpyrifos in the environment by reducing its availability against dissipative capability and its degradative. While the adsorption effect on the environment toxicity depends on the route of exposure [16]. Chlorpyrifos has low water solubility $(1.4 \mathrm{mg} / \mathrm{l})$, high soil absorption coefficient (average $\mathrm{Koc}=8498 \mathrm{ml} / \mathrm{g}$ ), and medium vapor pressure $(2.7$ $\times 10^{-3} \mathrm{~Pa}$ at $\left.25^{\circ} \mathrm{C}\right)[17,18]$.

In this study, methidathion residue active ingredient only is found in one sampling location from Sisalam village about $0.014 \mathrm{mg} / \mathrm{kg}$. Methidathion is a nonsystemic insecticide. Methidathion degradation in the environment is influenced by temperature and $\mathrm{pH}$. The half degradation of methidathion is reported during half day up to 41 days depending on the temperature and $\mathrm{pH}$. The higher the ambient temperature is, the easier the methidathion will be degraded. Methidathion easily degraded at alkaline $\mathrm{pH}$. In acidic conditions hydrolytic cleavage occurs mainly on the C-S bond, and under alkaline conditions cleavage occurs on the P-S bond. Methidathion has low water solubility of about $240-250 \mathrm{mg} / \mathrm{l}$ at $20^{\circ} \mathrm{C}$. These conditions increase the potential of methidathion compound to move off-site into water surface depending on the conditions and environmental factors. Methidathion compound adsorption coefficient on clay is about $2.8 \%$ with $\mathrm{Koc}=310$ [19].

In this study, the level of malathion residue active ingredient was found in the range of 0.13 to $0.36 \mathrm{mg} / \mathrm{kg}$ and it has higher amount compared with chlorpyrifos and methidathion residues. The persistence of malathion in the environment is affected by sunlight and ultraviolet light exposure. 
TABLE 3: Pesticides residue found in soil samples from agricultural land in some of Wanasari's village (organophosphate group).

\begin{tabular}{|c|c|c|c|c|c|}
\hline \multirow{2}{*}{ Active ingredients } & \multicolumn{4}{|c|}{ Concentration of residue in some villages $(\mathrm{mg} / \mathrm{kg})$} & \multirow{2}{*}{$\mathrm{LOD}(\mathrm{mg} / \mathrm{kg})$} \\
\hline & Tanjungsari & Sisalam & Dukuhwringin & Wanasari & \\
\hline Diazinon & $<$ LOD & $<$ LOD & $<$ LOD & $<$ LOD & 0.0101 \\
\hline Fenitrothion & $<\mathrm{LOD}$ & $<\mathrm{LOD}$ & $<$ LOD & $<\mathrm{LOD}$ & 0.0100 \\
\hline Methidathion & $<\mathrm{LOD}$ & 0.0140 & $<\mathrm{LOD}$ & $<\mathrm{LOD}$ & 0.0104 \\
\hline Malathion & 0.1370 & 0.1450 & 0.3630 & 0.1490 & 0.0104 \\
\hline Chlorpyrifos & 0.0630 & 0.0150 & 0.0140 & 0.0110 & 0.0101 \\
\hline Parathion & $<\mathrm{LOD}$ & $<\mathrm{LOD}$ & $<\mathrm{LOD}$ & $<\mathrm{LOD}$ & 0.0100 \\
\hline Profenofos & $<\mathrm{LOD}$ & $<\mathrm{LOD}$ & $<\mathrm{LOD}$ & $<\mathrm{LOD}$ & 0.0101 \\
\hline
\end{tabular}

Information: LOD: Limit of Detection.

Photolysis reaction occurs to reduce the toxicity of malathion. Malathion residue in the soil may also occur due to improper handling of current pesticide formulations during the mixing process, including the spill or practices usage and poor storage. Malathion is released into the atmosphere (in the form of gas) and can be transported back to the surface of the soil and water through wet deposition. Malathion rapidly degraded in the soil; the results of previous studies showed that half degradation began within hours to about 1 week. Malathion can also evaporate from the soil and in addition malathion moves very easily in the soil. The process of malathion leaching from the soil into the water is not possible due to the rapid degradation of this compound in the environment. Malathion is soluble in water and can move quickly into the ground despite its low persistence (1-25 days in the ground) [20-23].

Other active ingredients such as diazinon, fenitrothion, parathion, and profenofos are not detected by Gas Chromatography (GC-MS) caused by the differences of each compound persistence. In addition, previous research showed that physical properties of organophosphate chemistry are also expected to affect the concentration of some organophosphates which are not detected by GC-MS. The presence of pesticide residues in the soil could adversely affect soil fertility level. One indicator is to determine soil fertility using earthworm presence. Previous studies had investigated the effect of pesticides on earthworms and showed a $50 \%$ reduction of earthworm activity when incorporated into the soil contaminated by pesticides and $90 \%$ reduction occurs when pesticides are placed on the soil surface. The presence of earthworms is very important for the agroecosystem sustainability, but earthworms can be degraded by the intensive use of pesticides $[24,25]$.

3.5. The Decrease of Soil Quality (Qualitative Approach). Land degradation might occur after the application of large quantities of pesticides continuously. The results of interviews with shallot farmers in Wanasari Subdistrict indicated potential damage to the soil quality in their farms. As $85.5 \%$ of respondents said that the soil became hard, $81.8 \%$ stated that earthworm biomass was not found, and $76.4 \%$ of respondents admitted that the ground color changed to brown-white (Figures 1 and 2).

\section{Conclusions}

The study showed that different insecticides and fungicides were used in each growing season. This study found that farmers apply a lot of pesticides. Pesticides are applied once every three or four days. The mixtures for insecticides and fungicides used at least three types of variations with doses of 30-40 $\mathrm{ml}$ for each type. Excessive application of pesticides shows the potential for land degradation. Organophosphate residues that have been found in shallot farm are methidathion, malathion, and chlorpyrifos active ingredients at Tanjungsari village, Sisalam, Dukuhwringin, and Wanasari. The methidathion residue is about $0.014 \mathrm{mg} / \mathrm{kg}$, malathion residue revolves around $0.1370-0.3630 \mathrm{mg} / \mathrm{kg}$, and chlorpyrifos residue ranged from 0.0110 to $0.0630 \mathrm{mg} / \mathrm{kg}$. Researchers suggest testing the quality of soil in the laboratory to ensure the condition of the soil in the current agricultural environment. Routine assessment for soil quality and pesticides usage control can be considered to maintain a sustainable ecosystem.

\section{Conflicts of Interest}

The authors declare that they have no conflicts of interest.

\section{References}

[1] F. Azam, S. Farooq, and A. Lodhi, "Microbial biomass in agricultural soils-determination, synthesis, dynamics and role in plant nutrition," Pakistan Journal of Biological Sciences, vol. 6, no. 7, pp. 629-639, 2003.

[2] S. A. Reinecke and A. J. Reinecke, "The impact of organophosphate pesticides in orchards on earthworms in the Western Cape, South Africa," Ecotoxicology and Environmental Safety, vol. 66, no. 2, pp. 244-251, 2007.

[3] S. Yasmin and D. D'Souza, "Effects of pesticides on the growth and reproduction of earthworm: a review," Applied and Environmental Soil Science, vol. 2010, Article ID 678360, 9 pages, 2010.

[4] O. Espinoza-Navarro and E. Bustos-Obregón, "Effect of malathion on the male reproductive organs of earthworms, Eisenia foetida," Asian Journal of Andrology, vol. 7, no. 1, pp. 97-101, 2005.

[5] S.-P. Zhou, C.-Q. Duan, H. Fu, Y.-H. Chen, X.-H. Wang, and Z.-F. Yu, "Toxicity assessment for chlorpyrifos-contaminated 
soil with three different earthworm test methods," Journal of Environmental Sciences, vol. 19, no. 7, pp. 854-858, 2007.

[6] S. Zhou, C. Duan, X. Wang, W. H. G. Michelle, Z. Yu, and H. Fu, "Assessing cypermethrin-contaminated soil with three different earthworm test methods," Journal of Environmental Sciences, vol. 20, no. 11, pp. 1381-1385, 2008.

[7] E. T. Topp and G. Vallaeys Soulas, "Pesticides: Microbial degradation and effects on microorganism," in Modem Soil Microbiology, J. A. van Elsas, Ed., Modem Soil Microbiology, pp. 547573, Marcel Dekker Inc, New York, 1997.

[8] D. S. Jenkinson and D. S. Powlson, "The effects of biocidal treatments on metabolism in soil-I. Fumigation with chloroform," Soil Biology and Biochemistry, vol. 8, no. 3, pp. 167-177, 1976.

[9] S. P. Kale and K. Raghu, "Relationship between microbial numbers and other microbial indices in soil," Bulletin of Environmental Contamination and Toxicology, vol. 43, no. 6, pp. 941-945, 1989.

[10] P. C. Kearney and S. Kellogg, "Microbial adaptation to pesticides," Pure and Applied Chemistry, vol. 57, no. 2, pp. 389-403, 1985.

[11] M. M. Andrea, T. B. Peres, L. C. Luchini, M. A. Marcondes, A. Pettinelli Jr., and L. E. Nakagawa, "Impact of long term applications of cotton pesticides on soil biological properties, dissipation of $\left[{ }^{14} \mathrm{C}\right]$-methyl parathion and persistence of multipesticide residues," in Proceedings of the International Atomic Energy Agency, Vienna, Austria, 2001.

[12] B. Waryanto, M. A. Chozin, Dadang, and E. I. K. Putri, "Environmental efficiency analysis of shallot farming: a stochastic frontier translog regression approach," Journal of Biology, Agriculture and Healthcare, vol. 4, no. 19, pp. 2224-3208, 2014.

[13] G. W. Sasmito, Simulation Application Diagnosis Expert System for Pests and Diseases Plant Shallots and Chili Using Chaining foreward and Rule-Based Approach, Postgraduate Program, Diponegoro University, Semarang, Indonesia, 2010.

[14] S. S. Sexton, Z. Lei, and D. Zilberman, "The economics of pesticides and pest control," International Review of Environmental and Resource Economics, vol. 1, no. 3, pp. 271-326, 2007.

[15] V. V. Oberemok, K. V. Laikova, Y. I. Gninenko, A. S. Zaitsev, P. M. Nyadar, and T. A. Adeyemi, "A short history of insecticides," Journal of Plant Protection Research, vol. 55, no. 3, pp. 221-226, 2015.

[16] S. Y. Gebremariam, M. W. Beutel, D. R. Yonge, M. Flury, and J. B. Harsh, "Adsorption and desorption of chlorpyrifos to soils and sediments," in Reviews of Environmental Contamination and Toxicology, vol. 215, pp. 123-175, Springer, New York, NY, USA, 2012.

[17] K. D. Racke and J. R. Coats, "Comparative degradation of organophosphorus insecticides in soil: specificity of enhanced microbial degradation," Journal of Agricultural and Food Chemistry, vol. 36, no. 1, pp. 193-199, 1988.

[18] J. H. Cink, "Degradation of chlorpyrifos in soil: effect of concentration, soil moisture, and temperature," in Retrospective Theses and Dissertations, Iowa State University, Ames, Iowa, USA, 1995.

[19] CDPR, "Methidathion risk characterization document," Department of Pesticide Regulation California Environmental Protection Agency, 2007, http://www.cdpr.ca.gov/docs/emon/ pubs/tac/tacpdfs/methidathion/envfate_mthd.pdf.

[20] V. I. Tsipriyan and N. I. Martsenyuk, "Toxicological evaluationof photolytic degradation products of pesticides," Cig. Sanit, vol. 8, pp. 77-80, 1984.
[21] R. H. Neal, P. M. McCool, and T. Younglove, Assessment of Malathion and Malaoxon Concentration and Persistence in Water, Sand, Soil and Plant Matrices Under Controlled Exposure Conditions, Environmental Hazards Assessment Program State Of California Environmental Protection Agency Department of Pesticide Regulation, 1993.

[22] EPA, "Malathion," 2000, https://archive.epa.gov/pesticides/ reregistration/web/pdf/malathion-red-revised.pdf.

[23] K. L. Newhart, Environmental Fate of Malathion, California Environmental Protection Agency Department of Pesticide Regulation Environmental Monitoring Branch, 2006.

[24] B. Y. H. Nugroho, S. Y. Wulandari, and A. Ridlo, "Analisis Residu Pestisida Organofosfat Di Perairan Mlonggo Kabupaten Jepara," Jurnal Oseanografi, vol. 4, no. 3, pp. 541-544, 2014.

[25] C. H. Hogger and H. U. Ammon, "Testing the toxicity of pesticides to earthworms in laboratory and field tests," Bulletin OILB/SROP, vol. 17, pp. 157-178, 1994. 

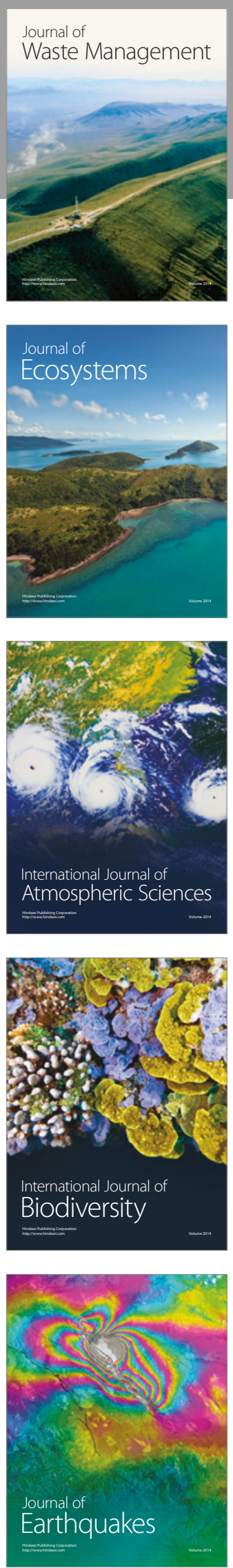
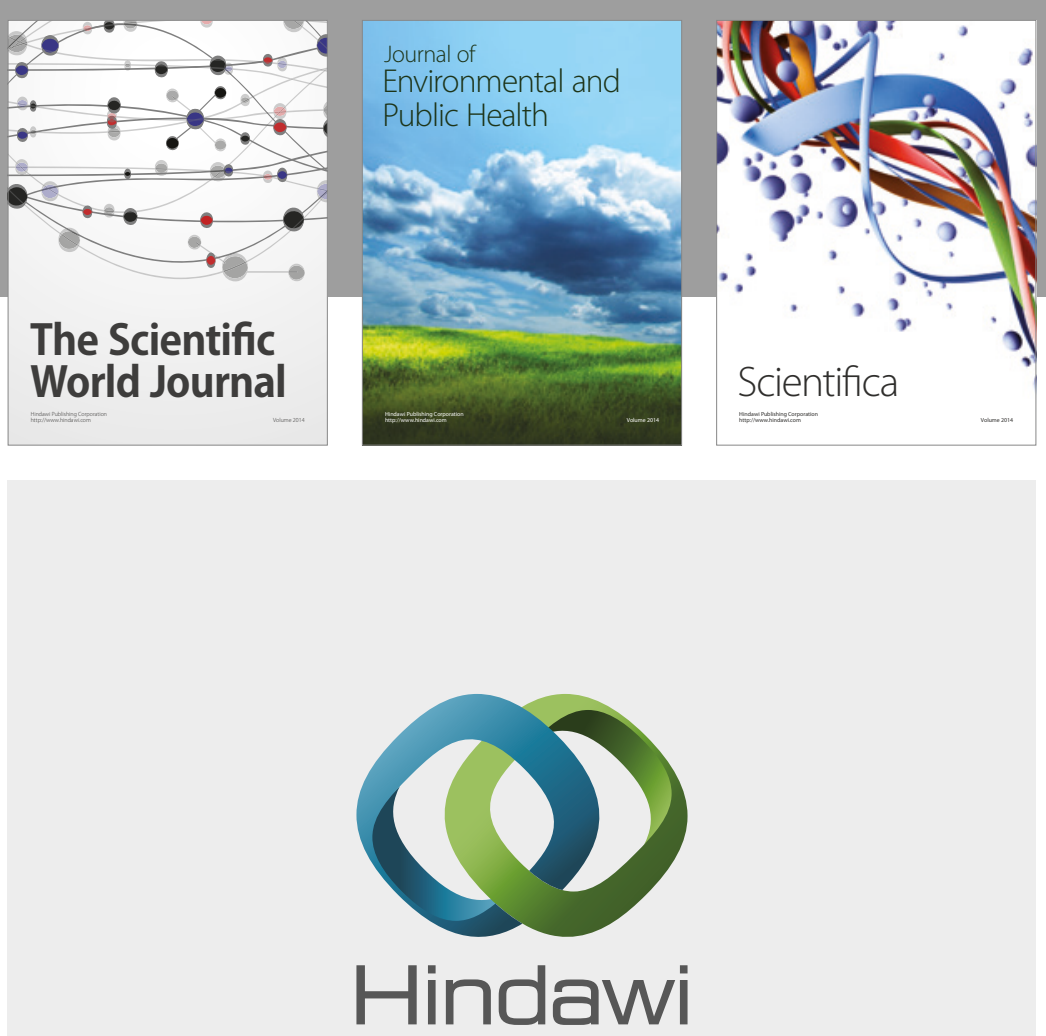

Submit your manuscripts at

https://www.hindawi.com
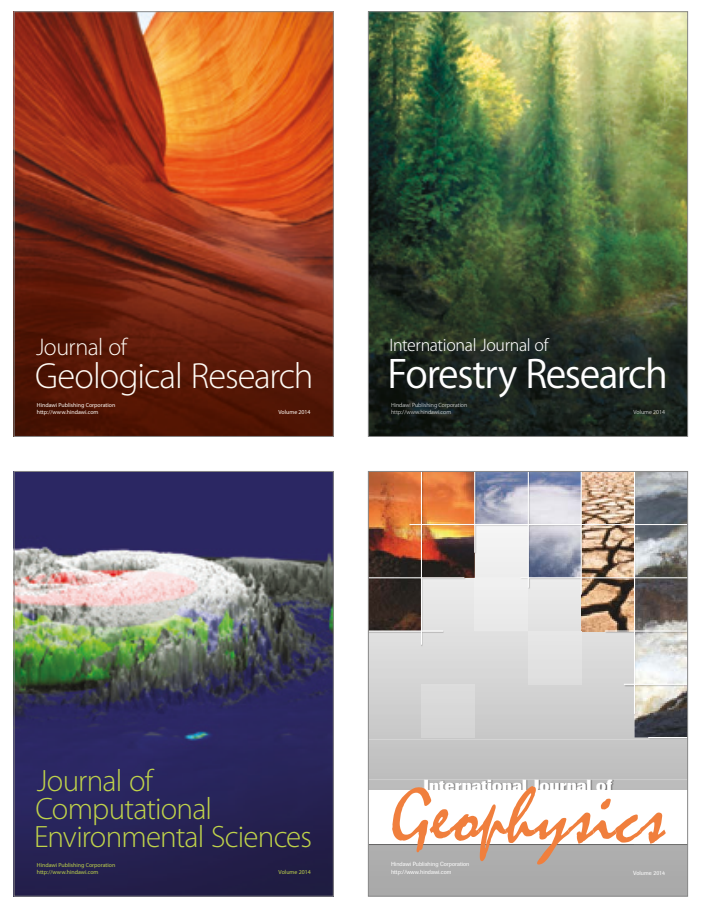
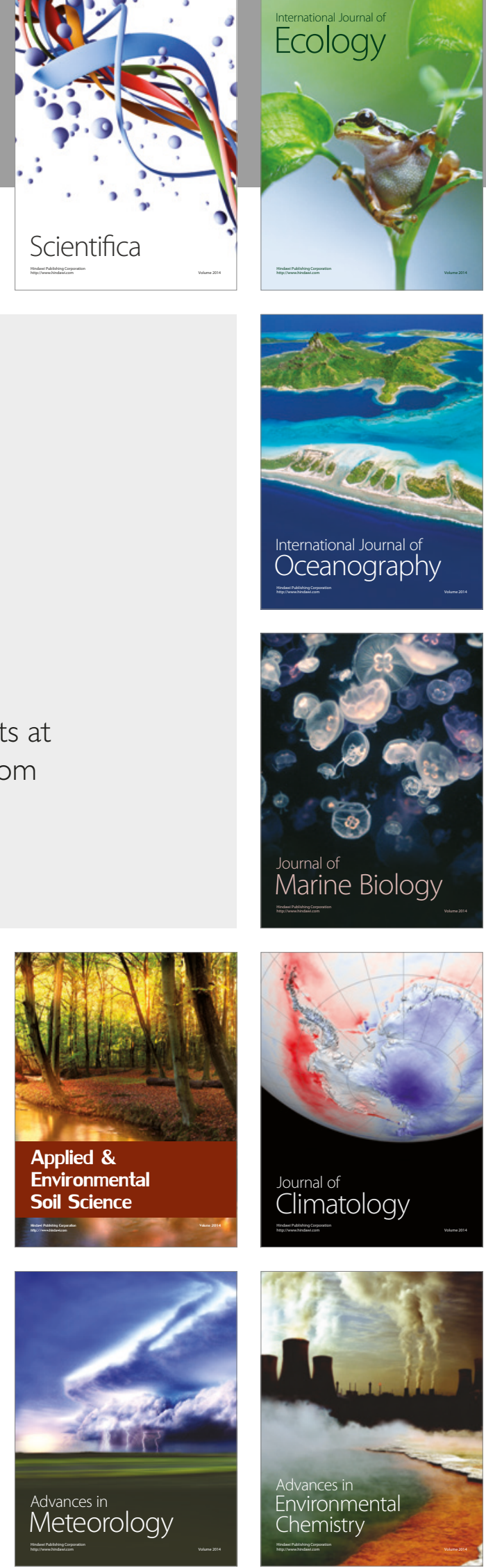